\title{
RECENT PROGRESS IN AVIATION.-II."
}

\author{
THE PRESENT STATE OF THE ART.
}

\section{B Y O C T A E C H A N UTE.}

\author{
Continued from Supplement No. 1803, Page 58.
}

Mean Whilde we may go back to September, 1908, and note some of Orville Wright's performances. He had at Washington the same general arrangement, consisting of a launching rail, launching derrick, and an apparatus for hoisting up the weights in order to give the machine impetus. This aeroplane is 40 feet across and has a breadth of $61 / 2$ feet. The front rudder is 16

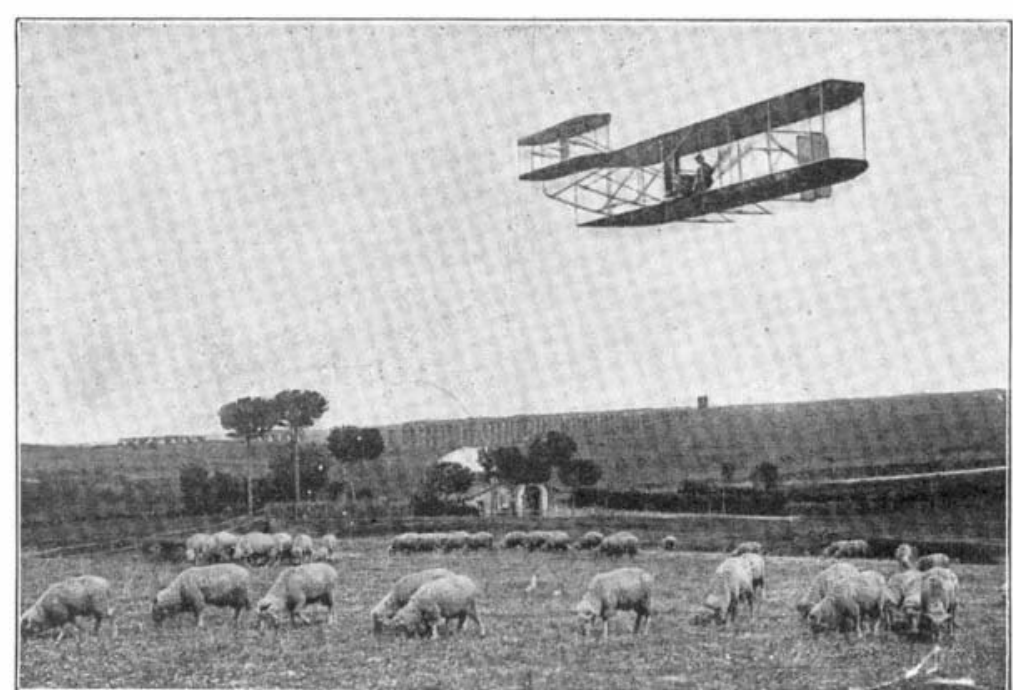

FIG. 10. - WILBUR WRIGHT AT ROME.

feet long, $2 \frac{1 / 2}{2}$ feet broad, and is enipped with skids, as shown in Fig. 7. The propeller is of peculiar and original construction and the motor is in every way the Wrights', for, in 1902, they made a canvass of the ifferent makers of gasoline motors in this country, asking them to furnish a motor according to specifications which they presented. None of them at that time could do so and the Wrights went to work themselves, designed a motor, and built it with their own hands. This design has proven more reliable than the motors built in France, which are unduly light. The Wright motor, originally of 15 pounds to the horse-power, was motor, originally of 15 pounds to the horse-power, was
reduced to 7 or 8 pound to the horse-power, while the French people are building motors weighing $4 \frac{1}{2}$ to 5 founds, but they do not prove as reliable, while the Wright motor has. never given any trouble and has proven reliable in every respect.

Orville Wright made a number of unofficial tests in 1908. On the 8th of September he rose to a height of 100 feet and flew 40 miles; on the 12 th he made a little higher ascension, estimated by the army officers at 200
feet, and fiew 50 miles in 1 hours and 15 minutes. Alto-
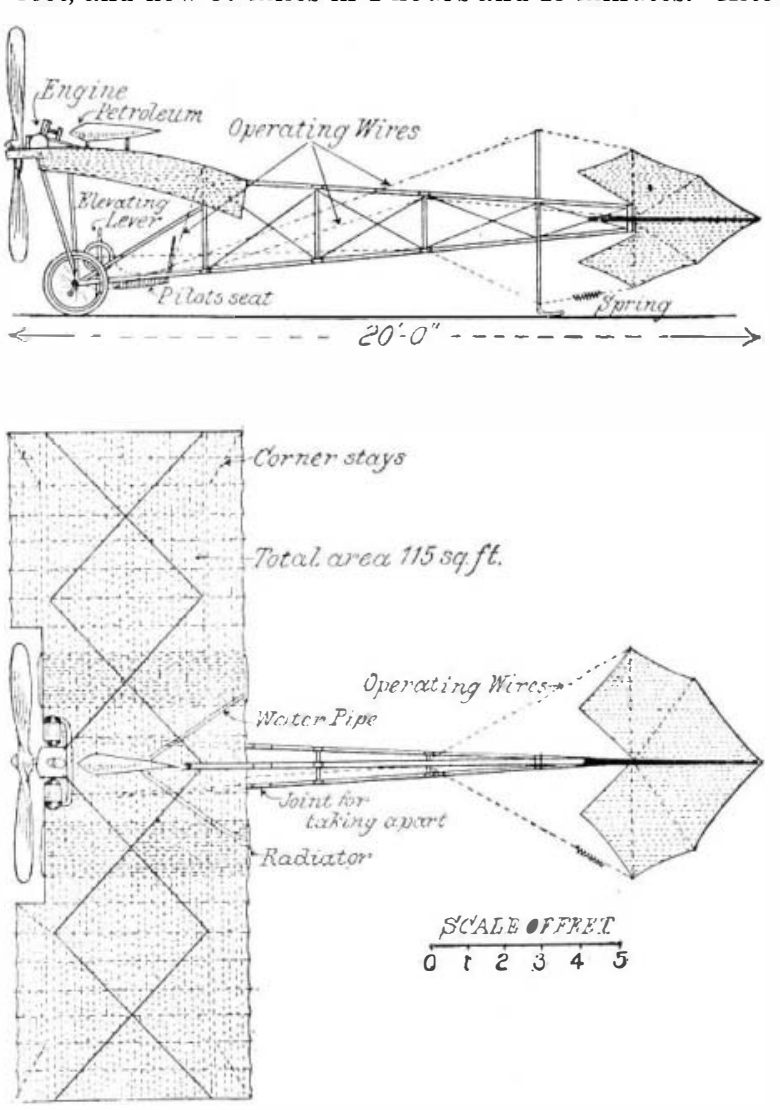

Fi木. 11.-ELEVATION AND PLAN OF SANTOS DUMONT'S NO. 20 MONOPLANE "DEMOISELLE."

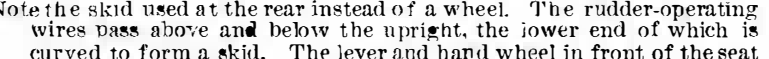
curved to form a skid. The jever and hand wheel in front of the
work the horizontal and vertical planes of the tail respectively. * Paper read before the Western society of Engineers, and here re
printerl from its journal. gether that year he made 14 flights. On the morning of the 17th of September he made several short flights. I the afternoon of that same ay he met with a terrible Selfridge were in mid-air, the machine falling to th earth, when Orville was seriously injured and Lieut Selfridge was killed. This ended the tests of that year. accident; his propeller broke while he and Lieutenan

The government granted an extension of time and the trials were not resumed until July of this year (1909). The results this year, as you know, have been very successful. The official time test shows that on the 27 th of July the machine remaine in the air for 1 hour and 13 minutes, with two persons on board

On the 30 th of July the machine traveled 5 miles and back cross-country in 14 minutes, with two persons on board, at a speed which averaged over 42 miles an hour. Therefore, the machine was accepted by the hove Therefore the gover pright is now engaged in teaching the army cfficers how to use the machine.

Immediately after the acceptance of the machine, Orville Wright went to Berlin, and there he has been accomplishing some remarkable feats.

On the 29th of August last he made his first exhibition there, flying 15 minutes. On the 8 th of September he went up with Captain Hildebrandt; on the 18th of ent, and on the 17 h of septemer he made a demonstrat fore the court. On the $2 d$ of October he took up into the air the Crown Prince, who gave him a handsome
present, and on the 4th of October he made a flight of

what had been done in this country, and they thought it would never o to let the Americans obtain priority in the air, so a good many people began to experi ment. Among the first was Santos Dumont, who made

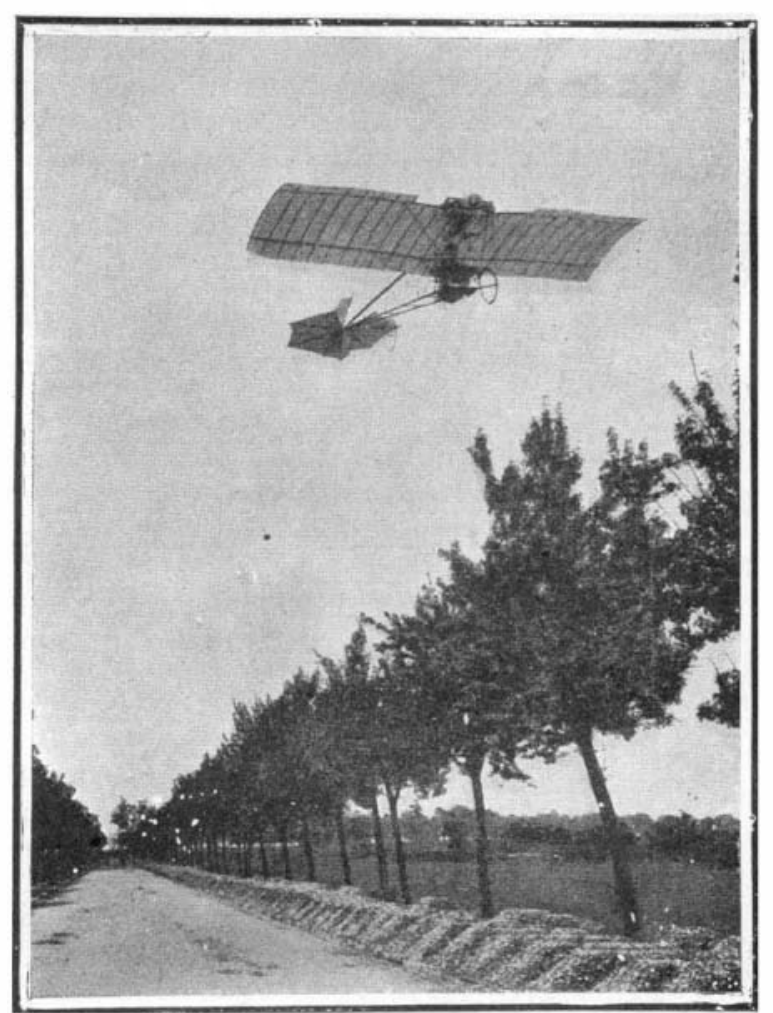

Fig. 12.-SANTOS DUMONT. ST. CYR .TO BUC. a flight on the 12th of November, 1906, of 720 feet in 21 seconds with his No. 14 machine, Hargrave type. That flight, created great excitement, and the French people thought they were on the high road to beat the Americans, but it required a good deal of further experimenting before that result was even partially accomplished.

Santos Dumont brought the machine out a second time, but broke it. He then conclude that it was not built on the right plan and began to experiment with a modified machine. It proved unsatisfactory in various ways, and after it was broken he discarde it.

The next machine he tried was the biplane, the cellular partitions being removed. That ought, in $\mathrm{my}$ judgment, to have given satisfaction, but it did not and he abandone it, although with that machine he made a flight, in Paris, on the 17th of November, 1907 of 500 feet.

He then went over to still another plan which he

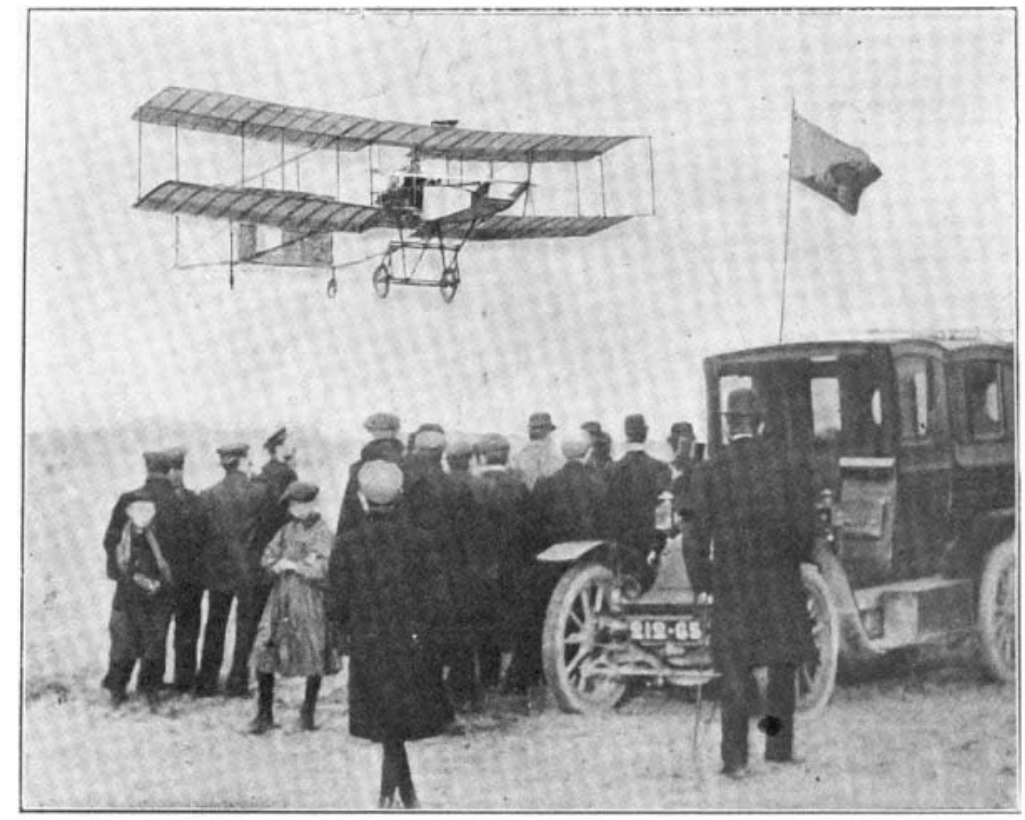

EIG. 13. DELAGRANGE ON THE VOISIN MICHINE.

21 miles, reaching a height estimated at 1,600 feet. This is the latest performance which he has made, although there is no telling what another day will bring forth $\mathrm{He}$ is now in Paris. In London he may make some demonstrations with his machine in the course of a week or two.

The French, in 1905, became partly acquainted with calle the "Bird of Prey." In this design he placed the motor up in the top and had a dihedral angle in the biplane. But that did not give him satisfaction, and in the next machine he finally went over to the monoplane, which the French people have always in monoplane, whe the French people have always in sisted was the best desinn for a flying machine, and 
Figure 11 is a view of the monoplane of Santos Dumont, and with that, on the 10th of March, 1909, he made a flight of 1,300 feet. On the 10th of April he made another flight of 1.2 miles. On the 19th of June he made a flight at Issy, near Paris, of 820 feet, at which time his machine was struck by a downward rush of air, and to his great astonishment he found himself suddenly on the ground. The machine had hime downden on the ground. The machine had gone down without his knowing what was happen-
ing. Fortunately the machine was not broken and he ing. Fortunately
was not injured.

was not injured.
Santos Dumont's idea had been all along to have a Santos Dumont's idea had been all along to have a
handy machine, and he finally built a baby monoplane, which he called the "Demoiselle" (Dragon Fly). This is: the smallest of all the existing aeroplanes. Its supporting surface is only 97 square feet; its weight 260 pounds. When that is compared with the Wright mapounds. Whe that 500 square feet of supporing maace and a weight of 950 pound (the empty machine), ace and a weight of 950 pound (the empty machine),
we can appreciate the enormous difference and the we can appreciate the enormous difference and the
necessity, therefore, of driving this Dragon Fly very much faster in order to obtain support from the air, with so very small a surface. On the 13th of September of this year, near Paris, Mr. Dumont was able to drive that machine five miles in five minutes, going down the wind or at the rate of 60 miles an hour years, have had to enlarge their shop three times to eep up with their orders.

In Fig. 13 is shown the machine the Voisin brother built for Delagrange. At first he did not trust himsel to fly the machine, but got Voisin to ride in it and show him how. Subsequently he flew in it himself and all the later feats he has accomplished by himself.

On the 11th of April, 1908, he flew 2.5 miles at Issy; on the 27 th of May, at Rome, 7.9 miles in 15 minutes and 26 seconds; at Milan, June 22d, 10.5 miles in 16 minutes and 30 seconds. Then he went to Turin an for the first time in history took a lady on board, who was very proud of the honor.

The picture, Fig. 14, is from the meet at Rheims in August, 1909, where Delagrange flew 31 miles on monoplane. It may be remarke incidentally that there have been lately uite a number of these tournaments in Europe, which have attracte great crowds, have proved very satisfactory, and where all previous records have been smashed. One was at Rheims, where the Champagne people contribute large sum for the experiments. Another tournament took place later in Berlin, and still another in Juvisy, near Paris, in October, 1909.

The next man to gain prominence was the celebrate sportsman, Henry Farman, who walked into the Voisin
He put both skids and wheels in this, the wheels being so adjusted that they could be lifted up, and with that apparatus splendid results were obtaine in the Champagne tournament. The apparatus is shown in Fig. 16.

On the 18th of July that machine flew for 1 hour and 23 minutes at Chalons. On the 23 of July he took a cross-country trip covering 40 miles from Chalons to Suippe. On the 27th of August his machine made flight of 112 miles at Rheims, which is the world' record for distance at present, ${ }^{1}$ and he received, therefore, the first prize in that tournament. On the sam day the machine flew 6 miles in 10 minutes with three persons on board, this being the first time three persons had ridden in a flying machine.

The next experimenter to be mentioned is Louis Blériot He began his experiments in 1906 , and has en more machines than any other aviator world. He has built twelve broken about fifteen, that being accomplished by re building the same machine after smashing it. $\mathrm{H}$ is a man of tremendous pluck and wonderful imagination, and therefore tries all sorts of things. The machine with elliptical cells was launche on floats in the Seine in order to haul it up as a kite, and was

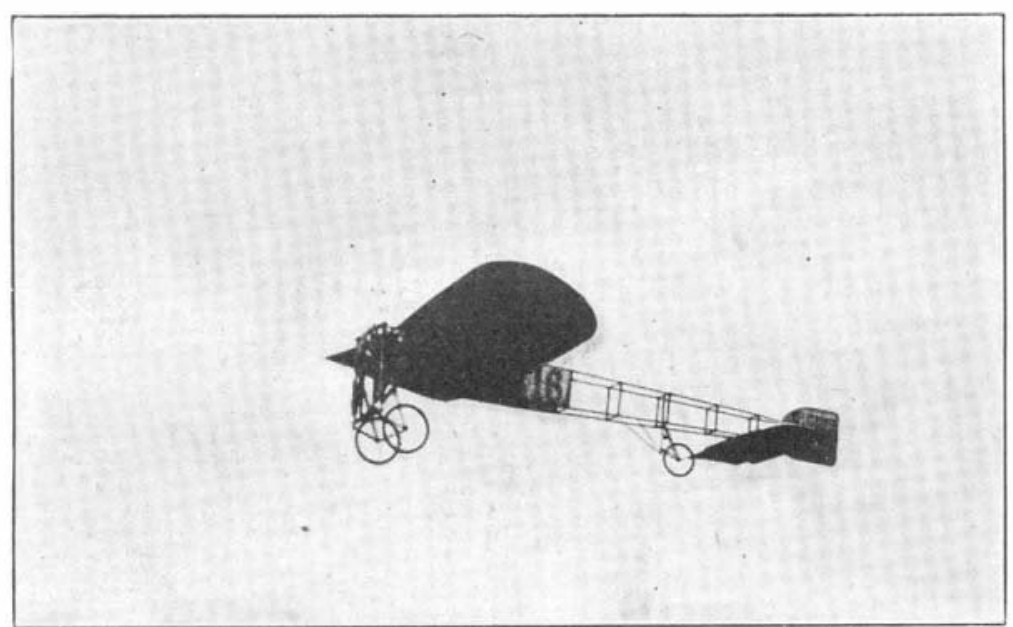

Fig. 14.-DELAGRANGE ON A MONOPLANE.

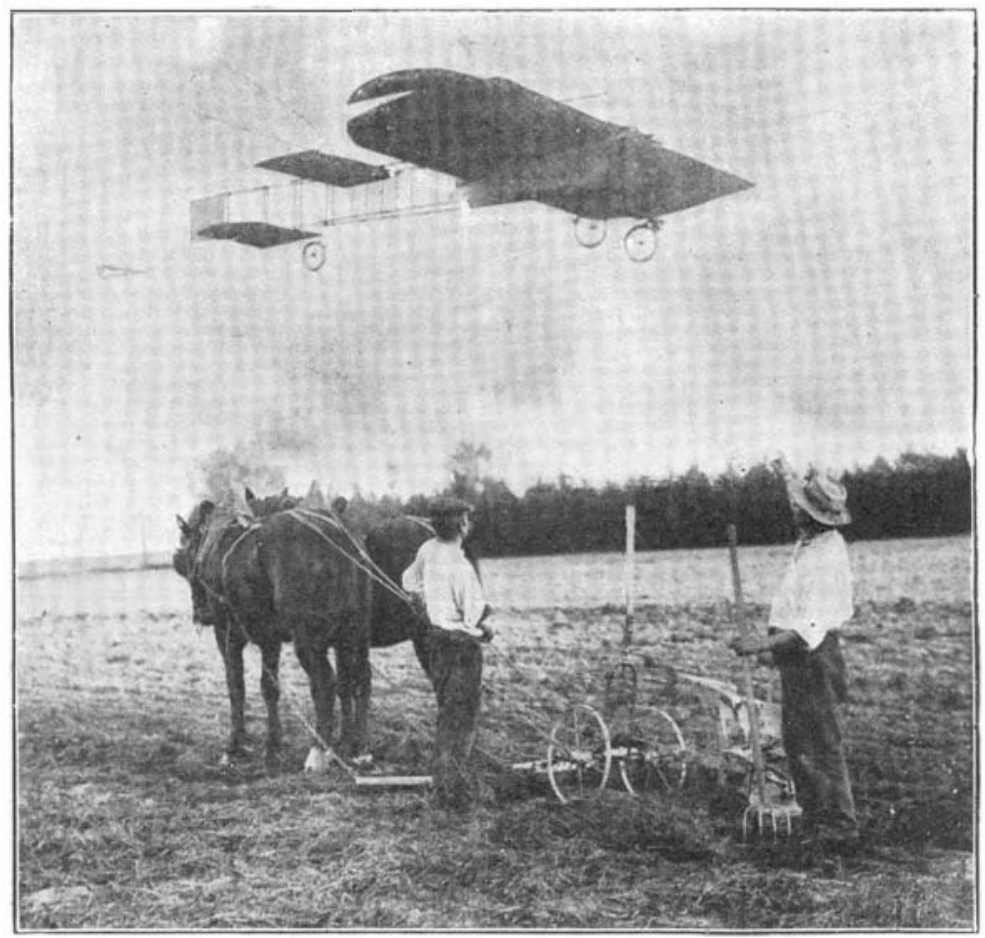

FiG. 17.-BLERI T'S MONOPLANE. ACROSS COUNTRY.

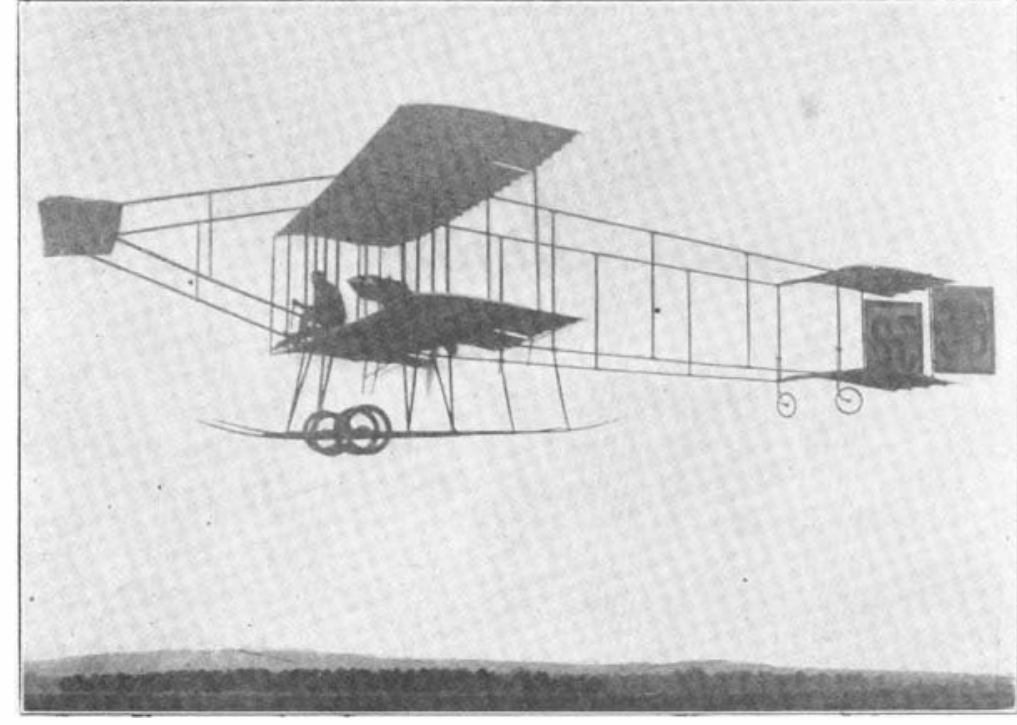

Fir. 16.-FARMAN'S BIPLANE.

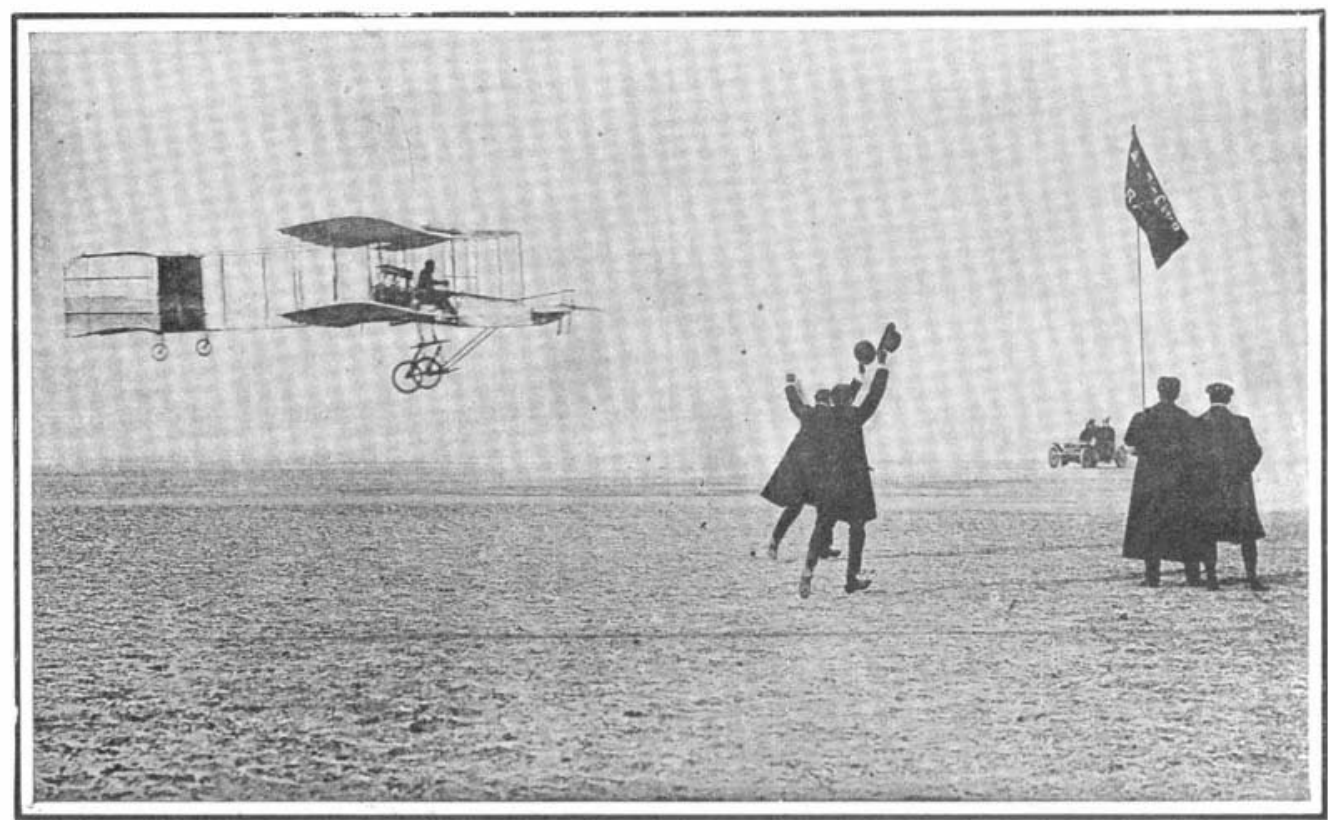

FIG. 15.-HENRY FARMAN'S BIPLANE IN FLIGHT. the ground. The speed through the air was probably about 50 miles an hour. Fig. 12 is from a photograph taken during that flight, which was from St. Cyr to Buc. I think the general idea is sound, for the smaller the flying machine can be made, within limits, the faster it must be made to go, and the more useful it is likely to prove for varying wind conditions. Commercially I have no clear opinion as to its uses, but as a mode of rapid transportation for very light loads, I think the smaller the aerial plane the better.

As regards the uestion which has lately been debated extensively, of the relative merits of the biplane and monoplane, I do not think we are yet in position to decide which is the better design. Both have their good points. The monoplane offers less resistance, but the biplane is steadier, stiffer, and stronger in every way. So it is only experience that will determine which one is the more efficient.

Other experimenters have come into the field, and among the first was a clever young sculptor by the name of Leon Delagrange. He went to Voisin brothers and aske them to build him an aeroplane. This was calle the Delagrange machine, but as a matter of fact the designing and construction was done by the Voisin brothers, who are a leading authority on the subject of building fying machines, and who, in two shop one day and ordere an aeroplane. He succeeded, cn the 26 th of October, 1907, in flying 253 feet, which at that time was considere a great feat. He then at. tempted to sweep a circle, but did not succeed. It really took the French people two years to learn how to turn a corner. They were somewhat misled at first by a mathematical equation, and then closely analyzed the motions of the bird. They found that he flexed cne wing at a lower angle than the other, placing himself thereby on a slant, so that the centripetal force of gravity should overcome the centrifugal force of the speed, and that similar effects could be produced by side fins and wing tips. Since that time they have turned corners without great difficulty but only on long radii.

Mr. Farman was successful, among other things, in sweeping curves on the 6th of July, 1908, when he flew 12 miles in 19 minutes and won the Armengaud prize which had been offere for the first turning of a corner. One of his flights is shown in Fig. 15.

On the 30th of October he made the first cross-coun try flight in history, by going from Chalons to Rheims 17 miles in 20 minutes, thus winning great applause and becoming the foremost aviator in France. In 1909 he designed and built a flying machine of his ow with which to compete at the Rheims tournament. rangement would increase the stability very much, but it did not, and he gave up that idea. He then constructed No. 4, which he called a box-plane.

Machine No. 5 was of the Langley type, on the sam plan that our army officers had been unable to obtai further funds to experiment with-two sets of wings, cne behind the other-he placed it on wheels, and with that type he got some very iair flights, flying 474 feet That was not enough for him, so he went from that to the monoplane and he has built, I think, six of them. Since then he has adhered to the so-called Dragon Fly plan and is now flying on No. 12. On the 13th of July, 1909, he flew 27 miles in 45 minutes. Fig. 17 shows the machine on which he made his journey cross-country from Etampes to Chevilly, a distance of 27 miles, and on that occasion he flew across a railway train, over one of the churches, and over various buildings.

On the 25th of July Blériot attempted to cross the British channel and succeeded. Fig. 18 is from a pho tograph taken on that occasion. That trip comprise a distance of 39 miles and was made in 37 minutes. It created great excitement, great applanse, and great 1 Since this talk, Mr. Farman made. on the $3 \mathrm{~d}$ day of November, 1909 a fight the tally estre 
wonder, although, as a matter of fact, it was perhaps not as difficult a feat as the previous flying across country, but it appealed very much more to the imag. ination.

Blériot then went to the meeting at Rheims in Champagne, and there exhibite some very good performances. He flew over the grandstand at a very great height, made a trip on the 27th of August of 25 miles in 41 minutes, winning the ninth prize for dis7 minutes and 48 seconds, winning the first prize for speed.

\section{( To be continued.)}

LIGHT ALLOYS.

By Waltek Rosenhain.

T'une problem of producing an alloy which shall combine great strength with a low specific weight has been before metallurgists ever since the commercial manufacture of aluminium became an accomplished fact; more recently, however, the reuirements, in the first 1) lace, of racing yachts, then of motor cars and of motor cycles, and, finally, the pressing problems of aerial navigation, have added a rapidly increasing importance to the whole question. At the present moment German manufacturers particularly are putting forth claims in regard to achievements in this direction which appear startling at first sight, and it is tance, while on the succeeding day he flew 6 miles in

to above cannot be employed in excessively thin sections, so that in many special cases, where the scantling of structural parts cannot be reduced to minute dimensions, while the strength re uire is not very great, light alloys may be employed with advantage as compared with alloy steel. The same argument applies, however, to a comparison made on similar lines between light alloys and the stronger kinds of wood. These woods are all considerably weaker, per square inch of sectional area than the light alloys now avaitlower density is taken into account, as well as the advantage of larger scantlings, the result must in many cases be favorable to the employment of wood. It is for this reason that the frames of most aeroplanes are constructed of wood. When, however, an alloy of density less than 3, and possessing a tensile strength of more than 20 tons per square inch under conditions allowing of a ductility equivalent to an extension of not less than 15 per cent on a 2-inch test-piece, becomes available, its employment will become advantageous as compare both with the best alloy steel and the best wood.

The light alloys available at the present time are somewhat numerous, and, as regards those of them which are patented or otherwise proprietary articles, it is difficult to obtain satisfactory data; it is certain, however, that extravagant claims are often advance for such alloys, and these are not verified when samples are trie in a testing machine.

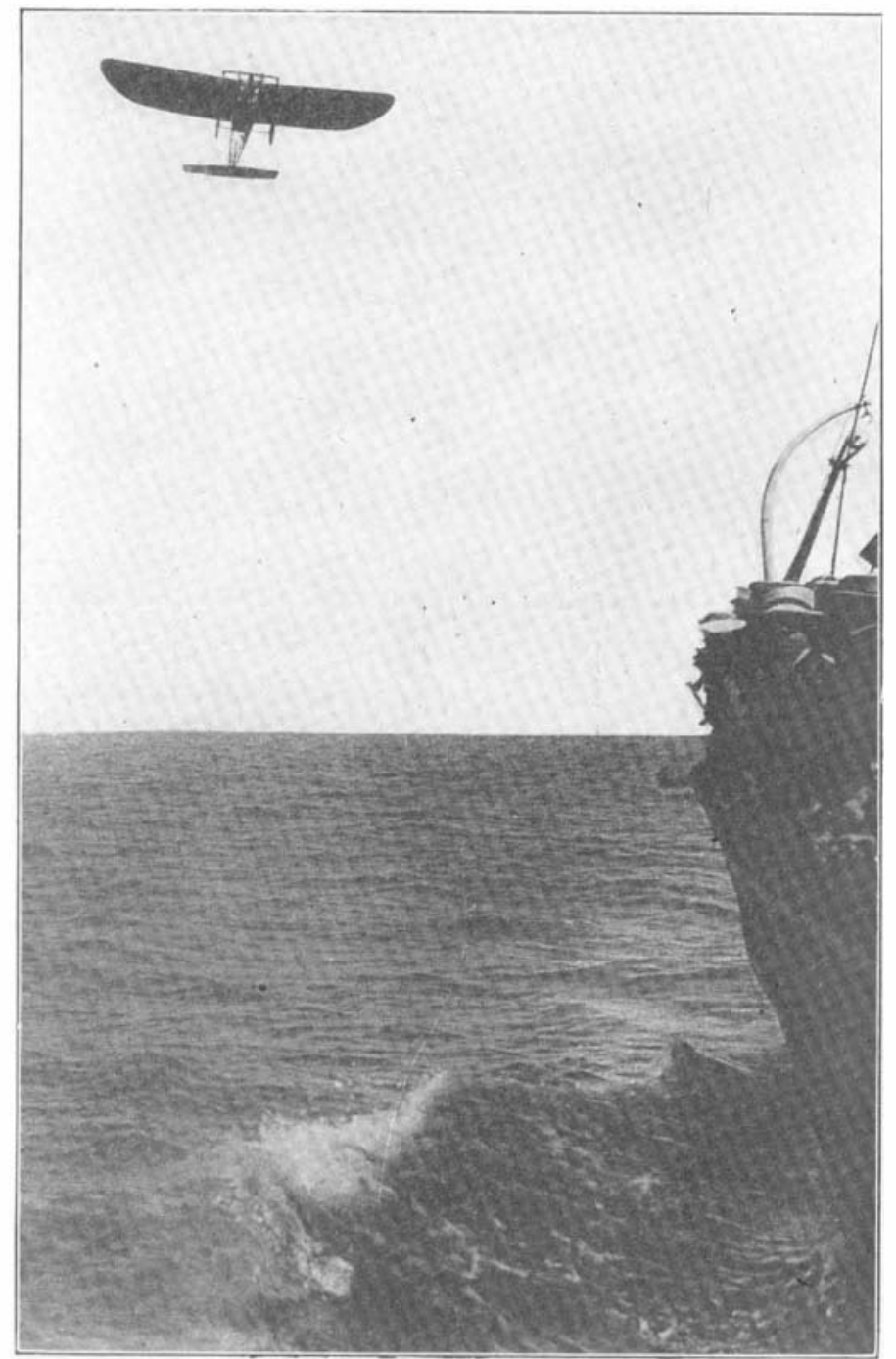

Fig. 18.-BLERIO'T'S MONOPLANE FLYING ACROSS THE CHANNEL.

interesting to examine the whole state of the question. The need for a light alloy lies in the fact that pure or nearly pure aluminium is, unfortunately, very weak mechanically. Its low specific gravity $(2.71)$ is more than counterbalance by the fact that its tensile strength, even in the form of rolled bars, does not cxceed 7 tons per square inch. If these figures are xcee 7 tons per suare inch. If these figures are compare with those of the best special alloy steels suitable for structural purposes, we find that some of these show tenacities up to 64 tons per square inch, with a density of approximately 7.9. Conse uently, a bar of aluminium, to bear the same ultimate load as a bar of such steel having a cross-sectional area of one inch, must have a sectional area of approximately (1) square inches, and would therefore weigh about three times as much as the steel bar. A light alloy which is to compete succes fully with is to conpete successfully with such special steels, h lighter than pure aluminium or it must combine with the density of aluminium a tensile strength of 21 tons per square inch

So far as alloys consisting principally of aluminium are concerned, it does not appear that this tensile strength has ever been attained, except in the case of hard-drawn wires the ductility of which has been re duced to an excessively low value. II must however, be borne in mind that the high-tension steels referre

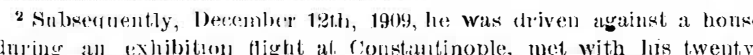

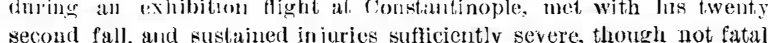
to require his going to a hospitial much higher, so that they can hardly be classed among the light alloys.

The light alloys at present employed in practice are principally used in the form of more or less complicated castings, such as motor-car engine crank-cases, the corresponding parts of aerial motors, and simila purposes. When thus used the alloys cannot be com pared with special alloy steels, and still less with wood and they hold the field quite easily against cast-irons, ness rather than uctility is esired, and alloys containing rather more than 4 per cent of copper, or the corresponding amount of manganese, can be employed. The casting of these alloys presents some difficulty, but a considerable number of founders are able to produce castings of this kind with regularity; the secret of their success lies largely in casting the alloy at a suitable temperature, and in the preparation of a mold having a hard and very dry surface. All the alloys of this class undergo a comparatively enormous amount of shrinkage in passing from the totally liquid to the totally solid condition, and unless due allowance is made for this contraction, faulty castings always result. In the case of the aluminium-zinc alloys, a difficulty of another kind arises; while these alloys are less viscous when molten, and flow into the molds more freely than the aluminium-copper alloys, they are very weak and brittle while hot, and castings made of these alloys are very apt to crack while cooling if their contraction is opposed to any considerable extent; it is probably on this account that these alloys have acuire the reputation of being "treacherous." They have, on the other hand, been employed with some success for the production of so-called "die castings." These castings are produce by means of metallic molds, and can be made so accurate that no machining is revire even for such objects as screwthreads and certain parts of instruments. On the other hand, these alloys are said to be weak under vibration, but this statement as yet reuires confirmation by systematic investigation.

The question of the power of light alloys to resist corrosive influences is one of considerable importance; it has been generally accepted by those accustomed to deal with aluminium and its alloys that the pure metal is much more resistant to corrosion than any of its alloys, and, as regards some of these, this view is undoubtedly correct. The numerous "solders" which is undoubtedly correct. The numerous "solders" which
have been advocate for jointing aluminium and its have been advocated for jointing aluminium and its
alloys all suffer very seriously from this point of view. It must, of course, be borne in mind that aluminium itself has a powerful affinity for oxygen, and only protects itself from rapid atmospheric oxidation by the formation of a very thin coating of oxide on all exlosed surfaces; if this coating is ruptured, as, for instance, by friction, continuous oxidation results, and the presence of an alloyed element in the form of a distinct constituent may cause such interruption. Again, the contact of aluminium with another metal, in the case of all those metals usually met with in engineering construction, leads to the formation of galvanic couples, and the consequent rapid corrosion of the aluminium. In this way also an alloyed element may intensify corrosion. On the other hand, it is eually possible that the presence oi an alloyed metal may improve the protective coating of oxide formed on the surfaces of the metal, and there is good reason to believe that the presence of copper produces this effect to somb extent, while the presence of manganese - as has recently been shown-facilitates the formation of a surface "patina" containing manganese oxide as well as alumina.

Even in the best circumstances, however, the protection of light alloys from corrosion is a most important matter, and this is accentuated by the difficulty of finding a suitable paint or varnish the constituents
of which not act upon aluminium - an action which generally takes the form of an interchange of oxygen between the pigment and the metal. Processes for ccating the light alloys with a less corrodible metal, such as copper, tin, zinc, etc., have been tried, but these modes of protection are accompanied by the risk of an increased amount of local corrosion owing to galvanic action, if the metallic coating is anywhere to galvanic action, if the metallic coating is anywhere
broken through. A more hopeful line of thought is to broken through. A more hopeful line of thought is to
be found in the development of processes for coating the alloys with an adherent layer of some inert compound of aluminium, much as iron and steel are coate with a layer of phosphate of iron in the "Coslettizing" process.

Finally, some reference may be made to the possibilities of the use of magnesium and its alloys for the production of light and strong materials of construction. The fact that magnesium has a specific struction. The fact that magnesium has a specific
gravity of only 1.74 at once suggests its use for such a purpose, but the fundamental objection lies in the fact that it is much more corrodible than aluminium, and that therefore the attainment of even moderate durability in its alloys must a problem of much difficulty. That some solutiou of this problem may have been found is suggested by the statement recently made that the newest German Zeppelin airship is to 